\title{
Chapter 9 \\ Distribution of Plutonium Isotopes in Marine Sediments off Japan Before and After the Fukushima Dai-ichi Nuclear Power Plant Accident: A Review
}

\author{
Wenting Bu, Jian Zheng, Qiuju Guo, Keiko Tagami, and Shigeo Uchida
}

\begin{abstract}
A large amount of radionuclides was released into the atmosphere and directly discharged into the ocean as a consequence of the Fukushima Dai-ichi Nuclear Power Plant (FDNPP) accident. The possible actinides, especially plutonium contamination in the ocean from the nuclear accident, attracted general public and scientific concern. In this review, we summarize studies of the distribution of $\mathrm{Pu}$ isotopes in the marine sediments off Japan before and after the FDNPP accident to assess possible $\mathrm{Pu}$ contamination from the nuclear accident. Our results suggested that there was no detectable additional Pu injection from the FDNPP accident in the marine environment $30 \mathrm{~km}$ off the FDNPP 1 year after the accident. The detectable $\mathrm{Pu}$ isotopes originated from global fallout and the Pacific Proving Ground close-in fallout.
\end{abstract}

Keywords FDNPP • Marine sediments $\bullet$ Plutonium isotopes

\footnotetext{
W. Bu

State Key Laboratory of Nuclear Physics and Technology, School of Physics, Peking University, Beijing, China

Research Center of Radiation Protection, National Institute of Radiological Sciences, Chiba, Japan

J. Zheng $(\triangle) \bullet$ K. Tagami $\bullet$ S. Uchida

Research Center of Radiation Protection, National Institute

of Radiological Sciences, Chiba, Japan

e-mail: jzheng@nirs.go.jp

Q. Guo $(\square)$

State Key Laboratory of Nuclear Physics and Technology,

School of Physics, Peking University, Beijing, China

e-mail: qjguo@pku.edu.cn
} 


\subsection{Introduction}

On March 11, 2011, the Fukushima Dai-ichi Nuclear Power Plant (FDNPP) was hit and damaged by a magnitude 9.0 earthquake in the Northwest Pacific about $130 \mathrm{~km}$ off the northeast coast of Japan and the following gigantic tsunami. As a result, large amounts of radionuclides were released into the atmosphere and directly discharged into the sea. More than $70 \%$ of the released radionuclides were deposited over the North Pacific Ocean [1]. Studies concerning the fission products, such as ${ }^{131} \mathrm{I}$ and radiocesium, were carried out intensively after the nuclear accident. However, information about actinides, especially the plutonium ( $\mathrm{Pu}$ ) isotopes, is limited.

$\mathrm{Pu}$ isotopes are of public and scientific interest because they are characterized by radiotoxicity and strong chemical toxicity. They contribute much to the longterm dose for humans because of their relatively long half-lives $\left({ }^{238} \mathrm{Pu}, 87.7\right.$ years; ${ }^{239} \mathrm{Pu}, 24,110$ years; ${ }^{240} \mathrm{Pu}, 6,561$ years; ${ }^{241} \mathrm{Pu}, 14.4$ years). Investigating the characterization of $\mathrm{Pu}$ isotopes in marine sediments is important for purposes of environmental monitoring and radiotoxicity assessment. Moreover, $\mathrm{Pu}$ isotopes are considered as new geochemical tracers for the study of oceanic processes, such as sedimentation and particle scavenging, and the isotopic composition of $\mathrm{Pu}$ $\left({ }^{240} \mathrm{Pu} /{ }^{239} \mathrm{Pu}\right)$ has been used as an important fingerprint for environmental radioactive source identification [2-5].

Abnormal atom ratios of ${ }^{240} \mathrm{Pu} /{ }^{239} \mathrm{Pu}$ and ${ }^{241} \mathrm{Pu} /{ }^{239} \mathrm{Pu}$, and activity ratios of ${ }^{241} \mathrm{Pu} /{ }^{239+240} \mathrm{Pu}$ and ${ }^{238} \mathrm{Pu} /{ }^{239+240} \mathrm{Pu}$, have been reported in surface soil and litter samples in the 20- to 30-km zone around the FDNPP [6, 7], suggesting the atmospheric release of $\mathrm{Pu}$ isotopes from the nuclear accident. For the marine environment, in previous studies $[8,9]$ we investigated the distribution of $\mathrm{Pu}$ isotopes in marine sediments collected in the Pacific Ocean, $30 \mathrm{~km}$ off the FDNPP site, from July 2011 to July 2012 after the nuclear accident. Sakaguchi et al. [10] determined Pu concentration in seawaters in the Pacific, $50 \mathrm{~km}$ off the FDNPP, and they observed no significant amount of extra components from the nuclear accident. However, possible long-term $\mathrm{Pu}$ contamination from the nuclear accident in the marine environment, especially in the Japanese near-coastal (within $30 \mathrm{~km}$ ) marine environment, remains unknown because so far no information on $\mathrm{Pu}$ isotopes in the released radioactive liquid and in the FDNPP near-coastal marine environment is available.

$\mathrm{Pu}$ isotopes are particle reactive and can be easily incorporated into the sediments in the marine environment. Radiocesium $\left({ }^{134} \mathrm{Cs}\right.$ and $\left.{ }^{137} \mathrm{Cs}\right)$ released from the FDNPP accident was detected in sinking particles collected from the deep sea in the Western North Pacific 1 month after the accident [11]. The sediment-water distribution coefficient of $\mathrm{Pu}$ is two orders of magnitude higher than that of Cs [12]. Thus, $\mathrm{Pu}$ could be more easily incorporated into the sediments, and $\mathrm{Pu}$ distribution in the marine sediments could give direct information about $\mathrm{Pu}$ contamination in the marine environment.

In this review, we first summarize studies about the distribution of Pu isotopes in the marine sediments off Japan before and after the FDNPP accident. Then, we compare the results to assess possible contamination by $\mathrm{Pu}$ from the FDNPP accident. Perspectives about future research are presented as well. 


\subsection{Distribution of Pu Isotopes in the Marine Sediments off Japan Before the Accident}

During past decades, the distribution of $\mathrm{Pu}$ isotopes in the Western North Pacific and its marginal seas have been studied intensively because of the potential application of $\mathrm{Pu}$ isotopes as geochemical tracers for oceanic processes and source identification of radioactive contamination. Before the FDNPP accident, $\mathrm{Pu}$ isotopes in the Western North Pacific off Japan originated from global fallout and the oceanic current-transported Pacific Proving Ground (PPG) close-in fallout. Global fallout $\mathrm{Pu}$ has been characterized by a ${ }^{240} \mathrm{Pu} /{ }^{239} \mathrm{Pu}$ atom ratio of 0.18 and a ${ }^{241} \mathrm{Pu} /{ }^{239} \mathrm{Pu}$ atom ratio of 0.0011 [13]. (For all the values discussed in this study, ${ }^{241} \mathrm{Pu}$ decay corrections have been made to March 11, 2011.) However, the PPG close-in fallout has higher $\mathrm{Pu}$ isotopic composition values $\left({ }^{240} \mathrm{Pu} /{ }^{239} \mathrm{Pu}\right.$ atom ratio, $0.30-0.36 ;{ }^{241} \mathrm{Pu} /{ }^{239} \mathrm{Pu}$ atom ratio, $\sim 0.0020)$ [14-17].

In our previous study [9], we determined the characterization of Pu isotopes in the sediments collected in seven Japanese estuaries facing the Pacific before the accident. Here, we summarized ${ }^{239+240} \mathrm{Pu}$ activity and ${ }^{240} \mathrm{Pu} /{ }^{239} \mathrm{Pu}$ atom ratios in the surface sediments in the marine environment off Japan, as presented in Fig. 9.1. ${ }^{239+240} \mathrm{Pu}$ activity was relatively low, especially for the Japanese river estuary sandy sediments, which ranged from 0 to $1 \mathrm{mBq} \mathrm{g} \mathrm{g}^{-1}$. The highest concentration $\left(5.81 \mathrm{mBq} \mathrm{g}^{-1}\right)$ of ${ }^{239+240} \mathrm{Pu}$ activity was reported in the surface sediment of Sagami Nada [18]. This high concentration was suggested to be caused by additional inputs of $\mathrm{Pu}$ from land origins (by rivers and by winds, followed by bioturbation) and the enhanced particle scavenging of transported PPG-source Pu [18, 21].

Studies on ${ }^{241} \mathrm{Pu}$ in the marine sediments off Japan before the nuclear accident are limited. Yamamoto et al. [22] determined $\mathrm{Pu}$ isotopes in the sediments in the Japan Sea and found that ${ }^{241} \mathrm{Pu}$ activity ranged from 4.5 to $7.5 \mathrm{mBq} \mathrm{g}^{-1}$, which was similar to the results observed by Zheng and Yamada [21] in a sediment core collected from Sagami Bay. The Japanese government investigated $\mathrm{Pu}$ isotopes in the surface sediments off Japan and reported ${ }^{241} \mathrm{Pu}$ activities less than $3.3 \mathrm{mBq} \mathrm{g}^{-1}$ [23]. However, as a result of the influence of the PPG close-in fallout, high ${ }^{241} \mathrm{Pu}$ activities (up to $19-33 \mathrm{mBq} \mathrm{g}^{-1}$ ) were observed in the sediment near Bikini Atoll [24].

${ }^{240} \mathrm{Pu} /{ }^{239} \mathrm{Pu}$ atom ratios in the Japanese near-coastal surface sediments ranged from 0.17 to 0.27 (Fig. 9.1). Almost all the values were generally higher than the value of global fallout (0.18), except in the marine sediments in Northern Japan, where global fallout was the dominant source. Comparison of ${ }^{240} \mathrm{Pu} /{ }^{239} \mathrm{Pu}$ atom ratios in the marine sediments in Japanese river estuaries with global fallout and PPG close-in fallout values is shown in Fig. 9.2. For the eastern estuaries facing the North Pacific, the average ${ }^{240} \mathrm{Pu} /{ }^{239} \mathrm{Pu}$ atom ratio was 0.231 . The high ${ }^{240} \mathrm{Pu} /{ }^{239} \mathrm{Pu}$ atom ratios clearly indicated the mixing of global fallout Pu and PPG close-in fallout $\mathrm{Pu}$ in the marine environment before the FDNPP accident. For the vertical distribution of ${ }^{240} \mathrm{Pu} /{ }^{239} \mathrm{Pu}$ atom ratios in sediment cores, high ${ }^{240} \mathrm{Pu} /{ }^{239} \mathrm{Pu}$ atom ratios, 


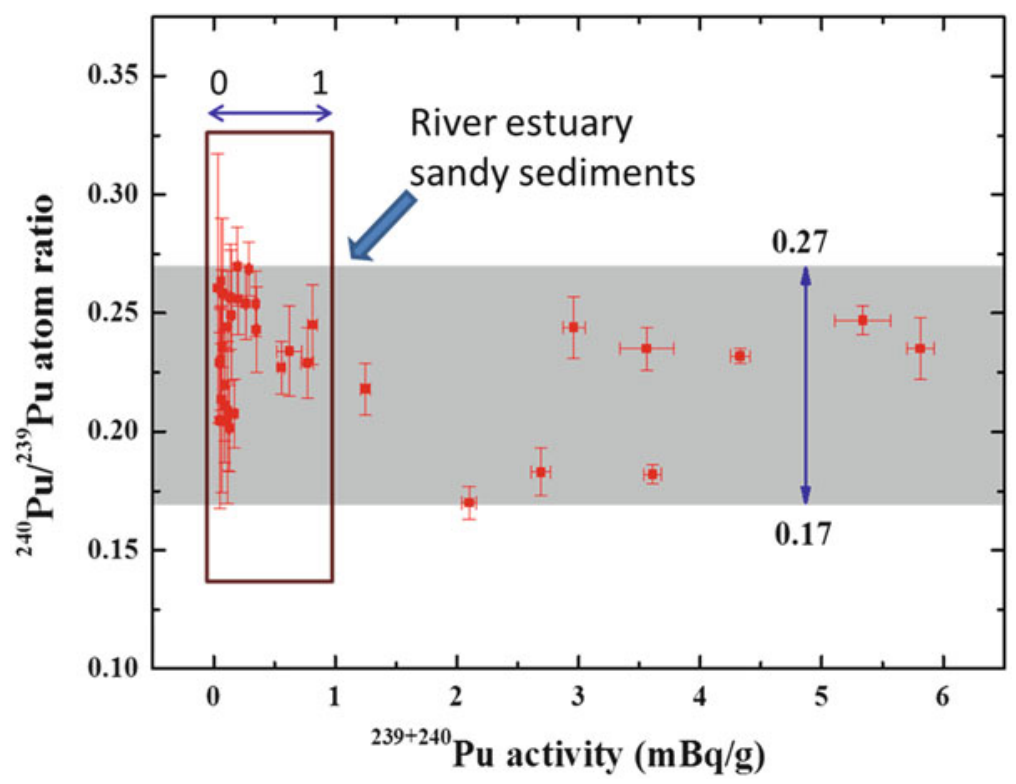

Fig. 9.1 ${ }^{239+240} \mathrm{Pu}$ activities and ${ }^{240} \mathrm{Pu} /{ }^{239} \mathrm{Pu}$ atom ratios in Japanese near-coastal marine sediments $(0-2 \mathrm{~cm})$. (Data from the literature $[9,18-20])$

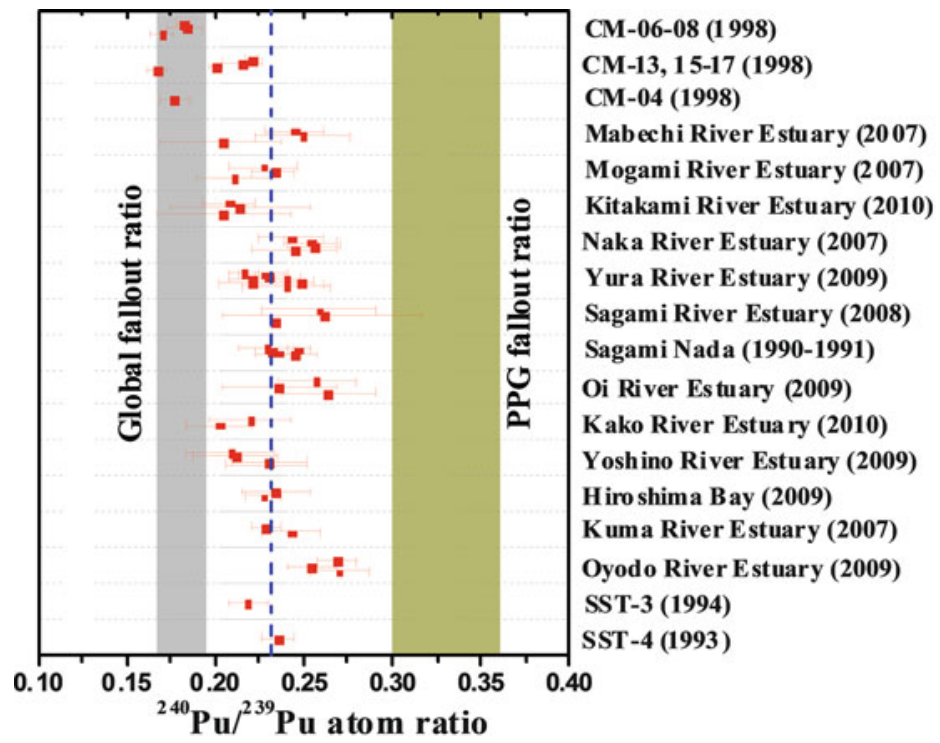

Fig. 9.2 The ${ }^{240} \mathrm{Pu} /{ }^{239} \mathrm{Pu}$ atom ratio distribution in surface sediments of Japanese river estuaries [9] 
up to $0.30-0.33$, have been found in the deeper layer $(>5 \mathrm{~cm})$ sediments from Okinawa Trough and Sagami Bay [25-27]. The high ${ }^{240} \mathrm{Pu} /{ }^{239} \mathrm{Pu}$ atom ratio in the deeper layer sediment could be caused by earlier deposition of PPG close-in fallout $\mathrm{Pu}$ isotopes.

From the reported results about the vertical distribution of $\mathrm{Pu}$ activities and atom ratios in the marine sediments in the Western North Pacific off Japan before the accident, we conclude that ${ }^{239+240} \mathrm{Pu}$ activity and ${ }^{240} \mathrm{Pu} /{ }^{239} \mathrm{Pu}$ atom ratio in the upper layer $(<5 \mathrm{~cm})$ sediments ranged from 0.02 to $5.38 \mathrm{mBq} \mathrm{g}^{-1}$ and 0.15 to 0.28 , respectively. For the deeper layer $(>5 \mathrm{~cm})$, the ${ }^{240} \mathrm{Pu} /{ }^{239} \mathrm{Pu}$ atom ratio could reach $0.30-0.33$ because of the influence of earlier deposition of PPG close-in fallout Pu. Inventories of $\mathrm{Pu}$ in the sediments varied significantly because the bottom topography and sediment dynamics in different sea areas are different. These results can be regarded as background data for $\mathrm{Pu}$ distribution in the marine sediments before the FDNPP accident.

\subsection{Distribution of Pu Isotopes in the Marine Sediments off Japan After the Accident}

To assess the impact of the Fukushima nuclear accident on possible Pu contamination in the marine environment, sediment core samples were collected in the Western North Pacific $30 \mathrm{~km}$ off the FDNPP during several cruises from July 2011 to July 2012 after the nuclear accident. The sampling information for each location is shown in Table 9.1. Pu distribution in surface sediments and sediment cores has been investigated $[8,9]$. Results for ${ }^{239+240} \mathrm{Pu}$ activity in the surface sediments, inventory-weighted ${ }^{240} \mathrm{Pu} /{ }^{230} \mathrm{Pu}$ atom ratios, and ${ }^{239+240} \mathrm{Pu}$ inventories for each sample station are presented in Fig. 9.3.

Table 9.1 Sampling information about the sediment cores collected in the western North Pacific off the Fukushima Dai-ichi Nuclear Power Plant (FDNPP) site after the nuclear accident

\begin{tabular}{lllcl}
\hline Sample & Cruise & Sampling time & Water depth $(\mathrm{m})$ & Location \\
\hline MC1 & MR 11-05 & 18 July 2011 & 1,327 & $36^{\circ} 28.97^{\prime} \mathrm{N}, 141^{\circ} 29.93^{\prime} \mathrm{E}$ \\
MC5 & MR 11-05 & 19 July 2011 & 141 & $37^{\circ} 35.01^{\prime} \mathrm{N}, 141^{\circ} 30.95^{\prime} \mathrm{E}$ \\
ES2 & KH 11-07 & 17 July 2011 & 2,200 & $37^{\circ} 4.00^{\prime} \mathrm{N}, 142^{\circ} 16.00^{\prime} \mathrm{E}$ \\
ES4 & KH 11-07 & 18 July 2011 & 5,400 & $37^{\circ} 53.00^{\prime} \mathrm{N}, 143^{\circ} 35.00^{\prime} \mathrm{E}$ \\
ES5 & KH 11-07 & 18 July 2011 & 7,300 & $37^{\circ} 47.00^{\prime} \mathrm{N}, 143^{\circ} 54.00^{\prime} \mathrm{E}$ \\
FS1 & KH 11-07 & 2 August 2011 & 150 & $37^{\circ} 20.00^{\prime} \mathrm{N}, 141^{\circ} 25.00^{\prime} \mathrm{E}$ \\
F1 & MR 12-02 & 7 July 2012 & 1,322 & $36^{\circ} 29.09^{\prime} \mathrm{N}, 141^{\circ} 30.01^{\prime} \mathrm{E}$ \\
\hline
\end{tabular}




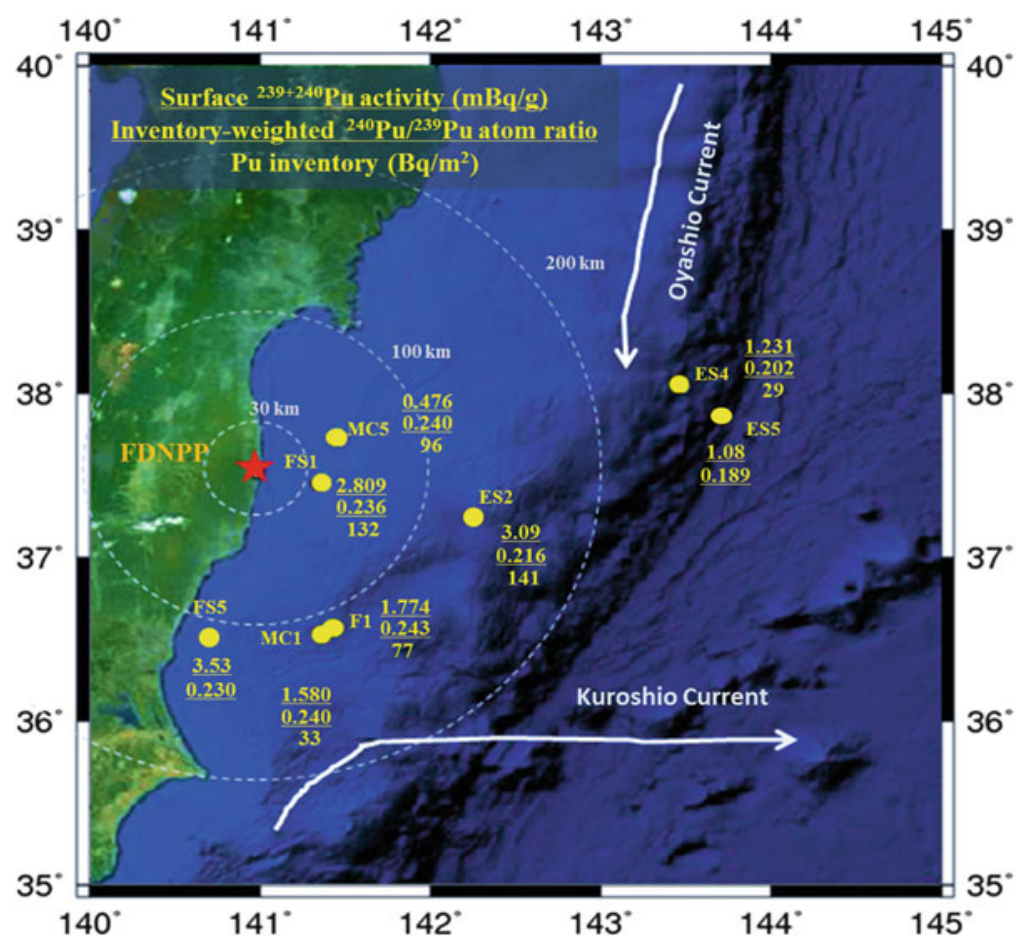

Fig. 9.3 Plutonium $(\mathrm{Pu})$ distribution in the marine sediments $30 \mathrm{~km}$ off the Fukushima Dai-ichi Nuclear Power Plant (FDNPP) site after the nuclear accident. (Data from references [8, 9])

\subsubsection{Distribution of Pu Activities and Pu Inventories}

Zheng et al. [8] reported $\mathrm{Pu}$ isotopic concentration in the surface sediments; the surface ${ }^{239+240} \mathrm{Pu}$ activities ranged from 0.48 to $3.53 \mathrm{mBq} \mathrm{g}^{-1}$. Bu et al. [9] investigated the vertical distribution of $\mathrm{Pu}$ isotopes in sediment cores. ${ }^{239+240} \mathrm{Pu}$ activities for all the surface sediments collected after the nuclear accident were less than $4 \mathrm{mBq} \mathrm{g}^{-1}$, typically less than the background upper limit data $\left(5.81 \mathrm{mBq} \mathrm{g}^{-1}\right)$ before the accident. Activity of ${ }^{241} \mathrm{Pu}$ in the investigated sediments was found to be quite low, most values being below the detection limit of $2 \mathrm{mBq} \mathrm{g}^{-1}$.

The inventories of $\mathrm{Pu}$ in the sediment cores ranged from 29 to $141 \mathrm{~Bq} \mathrm{~m}^{-2}$. High Pu inventories have been commonly reported in the coastal sediments in the Western North Pacific and its marginal seas. For example, $\mathrm{Pu}$ inventories in the Southern Okinawa Trough were extremely high (201-693 $\mathrm{Bq} \mathrm{m}^{-2}$ ) [25]. For the Japan Sea and Okhotsk Sea, $\mathrm{Pu}$ inventories ranged from 5.7 to $241 \mathrm{~Bq} \mathrm{~m}^{-2}$ and from 81 to $271 \mathrm{~Bq} \mathrm{~m}^{-2}$, respectively [27]. Therefore, isotopic composition information should be combined with the inventory to reach a more reliable conclusion. 


\subsubsection{Pu Atom Ratios}

The ${ }^{240} \mathrm{Pu} /{ }^{239} \mathrm{Pu}$ atom ratios in the surface sediments were between $0.188-0.255$, and for all the sediment cores collected after the accident, ${ }^{240} \mathrm{Pu} /{ }^{239} \mathrm{Pu}$ atom ratios ranged from 0.188 to $0.293[8,9]$, typically higher than the global fallout value $(0.18)$. ${ }^{240} \mathrm{Pu} /{ }^{239} \mathrm{Pu}$ atom ratios in the upper layers of the sediment cores showed nearly uniform distribution patterns, whereas for the sediment cores of MC1, FS1, and F1, the ratios increased from a definite depth. The higher ${ }^{240} \mathrm{Pu} /{ }^{239} \mathrm{Pu}$ atom ratios $(>0.25)$ could be attributed to the presence of the PPG close-in fallout Pu.

As shown in Fig. 9.3, the inventory-weighted ${ }^{240} \mathrm{Pu} /{ }^{239} \mathrm{Pu}$ atom ratios for the sediment cores ranged from 0.189 to 0.243 . The ${ }^{240} \mathrm{Pu} /{ }^{239} \mathrm{Pu}$ atom ratios for ES4 and ES5, which are located northeast of the FDNPP site, were lower than the values for the other stations. As the ES4 and ES5 stations are in the pathway of the Oyashio Current, they received more global fallout $\mathrm{Pu}$ than did the other stations investigated. The inventory-weighted ${ }^{240} \mathrm{Pu} /{ }^{339} \mathrm{Pu}$ atom ratio values were significantly lower than the reported values $(>0.30)$ for the FDNPP accident-released $\mathrm{Pu}$ [6] but typically in the background range before the nuclear accident.

The ${ }^{241} \mathrm{Pu} /{ }^{239} \mathrm{Pu}$ atom ratio observed in the surface sediments ranged from 0.0012 to 0.0016 , almost two orders of magnitude lower than the values $(>0.1)$ derived from the FDNPP accident [6]. As mentioned in Sect. 9.2, global fallout of Pu is characterized by a ${ }^{241} \mathrm{Pu} /{ }^{239} \mathrm{Pu}$ atom ratio of 0.0011 and $\mathrm{PPG}$ close-in fallout has a ${ }^{241} \mathrm{Pu} /{ }^{239} \mathrm{Pu}$ atom ratio $\sim 0.0020[13,16,17]$. The ${ }^{241} \mathrm{Pu} /{ }^{239} \mathrm{Pu}$ atom ratios in the Fukushima surface sediments were between the global fallout value and the PPG close-in fallout value. These results suggested that ${ }^{241} \mathrm{Pu}$ in the Fukushima surface sediment originated from global fallout and PPG close-in fallout.

\subsection{Sources of Pu Isotopes in Marine Sediments in the Western North Pacific off Japan}

\subsubsection{Influence of the FDNPP Accident on Pu Distribution}

FDNPP-derived $\mathrm{Pu}$ has been characterized by high atom ratios of ${ }^{240} \mathrm{Pu} /{ }^{239} \mathrm{Pu}$ $(0.303-0.330)$ and ${ }^{241} \mathrm{Pu} /{ }^{239} \mathrm{Pu}(0.103-0.135)$ [6]. Although the ${ }^{240} \mathrm{Pu} /{ }^{239} \mathrm{Pu}$ atom ratios in the sediments after the FDNPP accident were higher than the global fallout value, these values cannot be simply explained as the influence of the FDNPP accident because higher ${ }^{240} \mathrm{Pu} /{ }^{239} \mathrm{Pu}$ atom ratios were observed in a wide range of sea areas in the Western North Pacific before the accident as the result of the influence of PPG close-in fallout. Comparison of ${ }^{240} \mathrm{Pu} /{ }^{239} \mathrm{Pu}$ atom ratio and ${ }^{239+240} \mathrm{Pu}$ activity for the marine sediments in the Western North Pacific before and after the accident is shown in Fig. 9.4. All the data observed after the FDNPP accident were in the 
0.188-0.255 after the accident
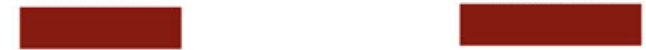

0.170-0.280 before the accident $\quad 0.01-5.81$

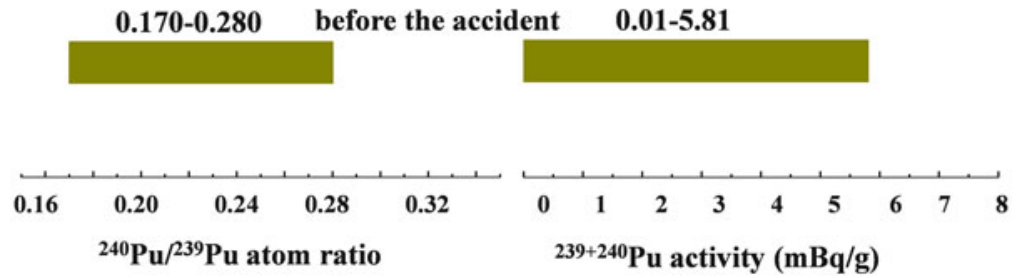

Fig. 9.4 Comparison of ${ }^{239+240} \mathrm{Pu}$ activities $\left(\mathrm{mBq} \mathrm{g}^{-1}\right)$ and ${ }^{240} \mathrm{Pu} /{ }^{239} \mathrm{Pu}$ atom ratios in the marine sediments off Japan before and after the FDNPP accident. (Data for Pu isotopes in the marine sediments after the FDNPP accident cited from references [8, 9])

background range before the accident. In the deeper layer sediments, higher ${ }^{240} \mathrm{Pu} /{ }^{239} \mathrm{Pu}$ atom ratios $(>0.25)$ were observed, which could be explained as the earlier deposition of PPG close-in fallout Pu, considering the sediment depth. Therefore, it can be concluded that no extra Pu injection from the FDNPP accident has been detected in the marine sediments in the Western North Pacific $30 \mathrm{~km}$ off the FDNPP site after the nuclear accident.

The data on the distribution of ${ }^{241} \mathrm{Pu}$ provide further support to this conclusion. The ${ }^{241} \mathrm{Pu} /{ }^{239} \mathrm{Pu}$ atom ratios in the Fukushima surface sediments were two orders of magnitudes lower than the values derived from the FDNPP accident. The ${ }^{241} \mathrm{Pu} /{ }^{239} \mathrm{Pu}$ atom ratios were between the global fallout value and the PPG close-in fallout value, thus further implicating global fallout and PPG close-in fallout source contributions to the investigated regions.

\subsubsection{Resolving Global Fallout and PPG Close-In Fallout Pu}

Because two sources (global fallout and PPG close-in fallout) of Pu contamination in the marine sediments off Fukushima are identified, a simple two-end-member mixing model was used to calculate the relative contributions:

$$
Y=\frac{(P u)_{\mathrm{P}}}{(P u)_{\mathrm{G}}}=\frac{\left(R_{\mathrm{G}}-R_{\mathrm{S}}\right)\left(1+3.66 R_{\mathrm{P}}\right)}{\left(R_{\mathrm{S}}-R_{\mathrm{B}}\right)\left(1+3.66 R_{\mathrm{G}}\right)},
$$

where $(\mathrm{Pu})$ is the ${ }^{239+240} \mathrm{Pu}$ activity, $R$ represents the ${ }^{240} \mathrm{Pu} /{ }^{239} \mathrm{Pu}$ atom ratio, and the subscripts $\mathrm{P}, \mathrm{G}$, and $\mathrm{S}$ refer to PPG close-in fallout, global fallout, and measured sediment samples, respectively. The inventory-weighted percentages of the PPG close-in fallout in each sediment core can be calculated by Eq. (9.1). 
The results showed that $\mathrm{Pu}$ in the sediment cores from the PPG contributed 16-43\% to the total Pu contamination [9]. The contribution of PPG close-in fallout $\mathrm{Pu}$ at ES4 station is $16 \%$, lower than the values (38-43\%) for the other stations. As discussed before, ES4 is located at the pathway of the Oyashio Current, which brought a large amount of global fallout Pu to that region. The contribution of PPG close-in fallout $\mathrm{Pu}$ in other stations is almost the same as the reported value (41\%) in CM-03 at the same sea area before the accident [27], suggesting there was no significant variability for the distribution of $\mathrm{Pu}$ isotopes in the marine sediments off the FDNPP site before and after the nuclear accident.

\subsection{Perspectives for Future Study}

We compared the distribution of $\mathrm{Pu}$ isotopes in the marine sediments before and after the FDNPP accident. From this comparison, we could not identify any additional $\mathrm{Pu}$ injection from the FDNPP accident into the marine environment outside the $30-\mathrm{km}$ zone after the accident. The Pu isotopes originated from global fallout and PPG close-in fallout. Recently, Perianez et al. [28] simulated the migration of the possible released Pu from the FDNPP accident in the Pacific Ocean, and they concluded that because of the low mobility of $\mathrm{Pu}$ in marine environment, if any $\mathrm{Pu}$ contamination from the FDNPP accident occurred in the sea, it would remain in an area very close to the FDNPP site. Therefore, the distribution of Pu isotopes in the marine sediments off the Fukushima Prefecture coast needs continuous investigation to reach a more comprehensive conclusion. We suggest that the following topics should be considered in future studies:

1. Expansion of the investigating intensity and area for the Pu distribution in the marine sediments off the Fukushima coast, especially for the marine sediments within the $30-\mathrm{km}$ zone.

2. Fractionation of $\mathrm{Pu}$ in marine sediments to understand the mobility and bioavailability of $\mathrm{Pu}$.

3. Investigation of $\mathrm{Pu}$ distribution and isotopic composition in seawater after the accident.

4. Study of Pu concentrations in marine biota to estimate the long-term dose influence of the FDNPP accident and to strengthen public confidence in the safety of seafood.

Acknowledgments This work was jointly supported by the Kakenhi Grant in Aid for Scientific Research on Innovative Areas (24110004) and the National Natural Science Foundation of China (A050507). Wenting Bu thanks the China Scholarship Council for offering a scholarship (20126010102) for supporting his Ph.D. study.

Open Access This article is distributed under the terms of the Creative Commons Attribution Noncommercial License which permits any noncommercial use, distribution, and reproduction in any medium, provided the original author(s) and source are credited. 


\section{References}

1. Yoshida N, Kanda J (2012) Tracking the Fukushima radionuclides. Science 336:1115-1116

2. Muramatsu Y, Uchida S, Tagami K, Yoshida S, Fujikawa T (1999) Determination of plutonium concentration and its isotopic ratio in environmental materials by ICP-MS after separation using and extraction chromatography. J Anal At Spectrom 14:859-865

3. Muramatsu Y, Ruhm W, Yoshida S, Tagami K, Uchida S, Wirth E (2000) Concentrations of ${ }^{239} \mathrm{Pu}$ and ${ }^{240} \mathrm{Pu}$ and their isotopic ratios determined by ICP-MS in soils collected from the Chernobyl 30-km zone. Environ Sci Technol 34:2913-2917

4. Zheng J, Yamada M (2006) Plutonium isotopes in settling particles: transport and scavenging of Pu in the Western Northwest Pacific. Environ Sci Technol 40:4103-4108

5. Ketterer ME, Watson BR, Matisoff G, Wilson CG (2002) Rapid dating of recent aquatic sediments using $\mathrm{Pu}$ activities and ${ }^{240} \mathrm{Pu} /{ }^{239} \mathrm{Pu}$ as determined by quadrupole inductively coupled plasma mass spectrometry. Environ Sci Technol 36:1307-1311

6. Zheng J, Tagami K, Watanabe Y, Uchida S, Aono T, Ishii N, Yoshida S, Kubota Y, Fuma S, Ihara S (2012) Isotopic evidence of plutonium release into the environment from the Fukushima DNPP accident. Sci Rep 2:304. doi:10.1038/srep00304

7. Yamamoto M, Takada T, Nagao S, Koike T, Shimada K, Hoshi M, Zhumadilov K, Shima T, Fukuoka M, Imanaka T, Endo S, Sakaguchi A, Kimura S (2012) An early survey of the radioactive contamination of soil due to the Fukushima Dai-ichi Nuclear Power Plant accident, with emphasis on plutonium analysis. Geochem J 46:341-353

8. Zheng J, Aono T, Uchida S, Zhang J, Honda MC (2012) Distribution of Pu isotopes in marine sediments in the Pacific $30 \mathrm{~km}$ off Fukushima after the Fukushima Daiichi nuclear power plant accident. Geochem J 46:361-369

9. Bu WT, Zheng J, Aono T, Tagami K, Uchida S, Zhang J, Guo QJ, Yamada M (2013) Vertical distribution of plutonium isotopes in marine sediment cores off the Fukushima coast after the Fukushima Dai-ichi nuclear power plant accident. Biogeosci 10:2497-2511

10. Sakaguchi A, Kadokura A, Steier P, Tanaka K, Takahashi Y, Chiga H, Matsushima A, Nakashima S, Onda Y (2012) Isotopic determination of U, Pu and Cs in environmental waters following the Fukushima Daiichi nuclear plant accident. Geochem J 46:355-360

11. Honda MC, Kawakami H, Watanabe S, Saino T (2013) Concentration and vertical flux of Fukushima-derived radiocesium in sinking particles from two sites in the Northwestern Pacific ocean. Biogeosci 10:3525-3534

12. IAEA (2004) Sediment distribution coefficients and concentration factors for biota in the marine environment, vol 422, Technical reports series. International Atomic Energy Agency, Vienna, pp 10-12

13. Kelley JM, Bond LA, Beasley TM (1999) Global distribution of Pu isotopes and ${ }^{237} \mathrm{~Np}$. Sci Total Environ 237(238):483-500

14. Buesseler KO (1997) The isotopic signature of fallout plutonium in the North Pacific. J Environ Radioact 36:69-83

15. Muramatsu Y, Hamilton T, Uchida S, Tagami K, Yoshida S, Robison W (2001) Measurement of ${ }^{240} \mathrm{Pu} /{ }^{239} \mathrm{Pu}$ isotopic ratios in soils from the Marshall Islands using ICP-MS. Sci Total Environ 278:151-159

16. Yamamoto M, Ishiguro T, Tazaki K, Komura K, Ueno K (1996) ${ }^{237} \mathrm{~Np}$ in hemp-palm leaves of Bontenchiku for fishing gear used by the fifth Fukuryu-maru: 40 years after "Bravo". Health Phys 70:744-748

17. Lachner J, Christl M, Bisinger T, Michel R, Synal HA (2010) Isotopic signature of plutonium at Bikini Atoll. Appl Radiat Isot 68:979-983

18. Zheng J, Yamada M (2004) Sediment core record of global fallout and Bikini close-in fallout Pu in Sagami Bay, Western Northwest Pacific Margin. Environ Sci Technol 38:3498-3504

19. Liu ZY, Zheng J, Yamada M, Pan SM, Kawahata H (2011) Plutonium characteristics in sediments of Hiroshima Bay in Seto Inland Sea in Japan. J Radioanal Nucl Chem 288:911-917 
20. National Institute of Radiological Sciences (2010) Report on biospheric assessment for waste, pp 29-30 (in Japanese)

21. Zheng J, Yamada M (2008) Isotopic dilution sector-field inductively coupled plasma mass spectrometry combined with extraction chromatography for rapid determination of ${ }^{241} \mathrm{Am}$ in marine sediments: a case study in Sagami Bay, Japan. J Oceanogr 64:541-550

22. Yamamoto M, Yamauchi Y, Chatani K, Igarashi S, Komura K, Ueno K (1990) Fallout ${ }^{237} \mathrm{~Np}$, $\mathrm{Pu}$ isotopes and ${ }^{241} \mathrm{Am}$ in lake and sea sediments from the coastal area of the sea of Japan. Radiochim Acta 51:85-95

23. MEXT (2008) Environmental radiation database. http://www.kankyo-hoshano.go.jp/08/ers_ lib/ers_abs53.pdf

24. Lee SH, Povinec PP, Wyse E, Pham MK, Hong GH, Chung CS, Kim SH, Lee HJ (2005) Distribution and inventories of ${ }^{90} \mathrm{Sr},{ }^{137} \mathrm{Cs},{ }^{241} \mathrm{Am}$ and $\mathrm{Pu}$ isotopes in sediments of the Northwest Pacific Ocean. Mar Geol 216:249-263

25. Lee SY, Huh CA, Su CC, You CF (2004) Sedimentation in the Southern Okinawa trough: enhanced particle scavenging and teleconnection between the Equatorial Pacific and Western Pacific margins. Deep Sea Res I 51:1769-1780

26. Wang ZL, Yamada M (2005) Plutonium activities and ${ }^{240} \mathrm{Pu} /{ }^{239} \mathrm{Pu}$ atom ratios in sediment cores from the East China sea and Okinawa trough: sources and inventories. Earth Planet Sci Lett 233:441-453

27. Zheng J, Yamada M (2006) Determination of Pu isotopes in sediment cores in the sea of Okhotsk and the NW Pacific by sector field ICP-MS. J Radioanal Nucl Chem 267:73-83

28. Perianez R, Suh KS, Min BII M (2013) Should we measure plutonium concentration in marine sediments near Fukushima? J Radioanal Nucl Chem doi: 10.1007/s10967-013-2422-1 